\title{
Dissonance in the discourse: A consumer's lens to national security
}

\section{Chiran Jung Thapa}

\begin{abstract}
This paper attempts to demonstrate the dissonance between the highlighted themes placing people at the epicenter and yet excluding the general public and their actual security needs, examines national security from a consumer's perspective. To underscore a dissonance in the discourse on national security, the writer explores the paradigm of national security policy. Then, it illustrates the discord between the public security needs in their everyday life and the outlined threats in the national security documents. To validate the above argument, the paper offers a new avenue on the overlooked consumer identity of human beings and demonstrates the probability and impact of threats to national security by means of the qualitative data analysis.
\end{abstract}

Keywords: dissonance, human existance, national security, threats, consumer security

\section{Introduction}

The paradigm of national security evolves itself steadily. Such an evolution process has been primarily influenced by the unyielding nature of national interests, changing nature of threats, the national and international context, the varying national capacities, priorities accorded to threats and the exploitation of useful opportunities. During the Cold War (1945-89), national security was calibrated primarily through military metrics because the martial realm dominated the national security outlook while security was highly deemed as a state and regime centric. The end of the Cold War, however, ushered a new comprehensive concept of national security. A rather idealistic and utopian concept labeled as "Human Security" was envisaged and widely peddled (UNDP, 2004). The concept of human security championed the idea of a world devoid of "want and fear." Then, Y2K episode that augurs the collapse of the computer operating systems around the world at the end of the millennium added a whole new dimension to the national security discourse. The September 11 terrorist attacks on the United States in the year 2001 and its subsequent actions totally altered the national security priority the world over.

\section{National security framework}

The theoretical framework of national security is derived from an aggregate of two separate concepts: nation and security. The basis of what constitutes a nation in recent years is no longer confined to a traditional formulation. It has clearly transcended beyond the realm of being just a social community with certain historical and cultural commonalities. "We are a nation of Christians and Muslims, Jews and Hindus, and non-believers. We are shaped by every language and culture, drawn from every end of this Earth" (Phillips, 2009). These afore-mentioned lines from the President Barack Obama's inaugural speech best illustrate the evolving nature of a nation's concept as it accommodates diversities. Likewise, the concept of security too has expanded. In the past, security generally had 
a military connotation and mostly entailed an element of force. Now, it encompasses various other elements as it transcends beyond just protection and preservation of an identity from physical harm. It now entails the ideas of economic, social, environmental and even psychological well-being.

Another fundamental change stems from the nature of threats. During the Cold War, the threats that dictated national security agenda were primarily military in origin and it emanated from beyond the national borders. Following the end of the Cold War, however, the threat of inter-state war with military confrontation particularly between two major rivals diminished. Instead, other threats that are more nuanced, complex, asymmetric and trans-national in nature became more palpable. National security discourse remains predominantly centered on the anticipation, prevention and mitigation of large-scale threats to the nation (The White House, 2015). These threats are prioritized mainly because the probability and the impact it would have on the nation. These threats have the potential to cause significant disruption and devastation on the nation and a national response is warranted to counter/mitigate these threats. A diverse range of threats like global warming, natural/manmade disasters, nuclear proliferation, health epidemics, resource depletion, terrorism, and cyber intrusions, misuse of artificial intelligence have now begun to dominate the national security agendas (The White House, 2017).

Similarly, the notion that national security can be attained unilaterally through national ways and means is increasingly becoming a less viable option. The world is now highly interdependent and interconnected. The global fabric is woven by an intricate web of dependencies through the relentless flow of goods, services, information and people. Even the major threats that afflict the nations are complex and transnational in nature. Such interdependency and inter-connectedness and the trans-national nature of threats limits the nations' ability to unilaterally provide comprehensive security to its denizens. Even the most endowed nations are unable to unilaterally tackle threats that are global in nature. Therefore, it renders cooperation as an indispensable variable for threat mitigation. Therefore, it would not be an over statement to postulate that the hallmark of national security in now "coordination, cooperation and collaboration."

The formulation of a national security strategy comprises of several undertakings (Staal, 2017). It involves a sober and dispassionate appraisal of the internal and external context. Threats and opportunities are identified. National interests, priorities and objectives are listed national (Security Concept of Mongolia, n.d). Means/resources to realize those objectives in the most optimal manner are outlined. Feasibility, affordability and sustainability of the strategy are calibrated. All of these are then intersected with the national vision of the government while considering national interest, national power and national will. Ultimately, a national security strategy that is holistic in nature is engineered from the above. Since the objective of a national security is to strengthen the nation on all possible realms and reduce vulnerabilities, it will comprise of all sectors. Education, Environment, Economy, Energy, Health, Diplomacy, Social, Information-Technology, Agricultural, Defense and many other sectors dovetail seamlessly to form the national security composite. 


\section{Encompassing exclusionary exercise}

The first line in President Barack Obama's national security strategy of 2015 outlines: "The United States government has no greater responsibility than protecting the American people" (The White House, 2015). Similarly, under a different political dispensation, President Donald Trump's National Security Strategy of 2017 explicitly mentions: "This National Security Strategy begins with the determination to protect the American people, the American way of life, and American interests" (The White House, 2017). These sentiments reflect that the people are at core of the national security agenda and protecting the people from any kind of harm remains the primary national goal.

Is national security policy/strategy a true reflection of the priorities of the populace belonging to a particular nation while the people should be at the core of any national security agenda? Does the prioritization of threats and opportunities by the government align with that of the public sentiment? Is there is a process whereby a majority of public viewpoints and priorities are duly assimilated during the formulation of such policy?

The prevailing approach to national security posits the duly elected government as the true representatives of the people thereby rendering them the sole prerogative of formulating and enacting policies on behalf of the people they serve. National Security Strategy formulation is most of countries reviewed appears to be an exclusive affair. Only a handful of people from the government and/or government ministries and departments, a few related outside experts are consulted in the formulation process (U.S. GAO, 2018). Generally, it is spearheaded by the members and staff of the
National Security Council. In addition, there are instances where the endorsement of the parliament is imperative for accountability and acceptance purposes.

Due to these limited consultations, there is a clear disconnect in the National security strategy formulation and the actual public sentiment. The national security formulation process is an elitist and exclusionary affair as most of the process is discreet. The only those with access to power and educated can have access and can influence the discourse. The U.S. Government Accountability Office (GAO) report explicitly mentions that "to identify long-range emerging threats, GAO administered a questionnaire to 45 government organizations that assess emerging threats across DOD, State, DHS, and ODNI, and had a 78-percent response rate (U.S. GAO, 2018). Even from a mathematical point of view, the maximum majority of the populace will have no say, no role but will have to shoulders the burden and/or be impacted by the national security agenda. No such priority, however, seems to be accorded to intimately connecting with the larger public to acquire their true security needs. On a topic that is so critical to every human's existence, the national security framework remains critically deficient in accommodating the larger public requirements. The dissonance becomes apparent when an agrarian community dwelling in the remote village is intersected with the threats outlined in the national security outlook. Most of the village dwellers would most likely not even be acquainted to issues such as nuclear security, terrorism that are emphatically outlined as the gravest national security threat. Most denizens will neither have the aptitude, interest or the reach to influence in these affairs. 


\section{Consumer lens}

The fundamental principle of security is the protection and preservation of life. Aside from exceptional cases where certain cause, belief or priority that may trump over the priority of life, the inception point for human pursuit of security has exclusively remained anchored in preservation of life. The other security imperatives, such as liberty and property follow thereafter.

Any human existence is contingent upon three indispensable requisites. A human being requires air/oxygen, water, and food the most to sustain life. With rare exceptions aside, an average human being can survive without oxygen for up to a few minutes, without water for a few days and without food for up to few weeks (Kane, 2016). This illustrates how human security is inextricably linked to the consumption of basic essentials. The whole identity of a human ceases devoid of these basic life sustaining imperatives.

At the core, the purpose of any national security strategy is to protect, preserve and perpetuate national identity. This essentially means the protection of individuals that dwell in the nation. Currently, an innate identity of all humans regardless of nationality, race, religion, class or age is the consumption pattern. All humans now are inextricably consumers of goods and services. Any disruption, distortion or deficiency in the consumption pattern would pose a serious threat to most human beings.

One example suffices to underscore how significant consumption is to National Security. The sheer magnitude of impact andprobability can be weighed through some of the food recalls that have been made in human history. On August 2011, the ground turkey costing $£ 36$ million was recalled in the United States on the suspect of contamination of a drug-resistant strain of salmonella (Reuters, 2011). Salmonellosis is life threatening disease. Even considering the minimalist threshold, with a consumption rate of 10 pounds per person, those affected would be 3.6 million people. Given this magnitude, the threat to national security is apparent.

Besides, the example above we human intersect with innumerable products on a daily basis. The probability, impact and permutation analysis are sufficient to infer the threats to humans on a daily basis. More than the threats that are so dominant on the national security agenda such terrorism or cyber-attack, the likelihood of larger people being impacted as a result of adulterated and/or sub-standard product is exponentially higher.

Moreover, most of the security concepts envisaged have human consumption at the core. Today nations are greatly engrossed in the security themes, such as maritime security, financial security, energy security, food security, cyber security and environmental security. These themes are innately connected with human consumption. These are all geared towards ensuring the undisrupted continuity of the national consumption cycle. Even climate crisis that is now being labeled as an existential threat has its origins in human consumption. The alarming climate crisis is not a cause rather a consequence of voracious human consumption.

Similarly, intersecting consumption with the capability of security agencies can shed enormous light on the significance of consumption perspective to national security. National security entities are ordained with 
the principal task of deterring and defending against all hostile threats. All security agencies currently are intrinsic consumers of innumerable consumable products and services. To fulfill the national security objective, security providers first need to be physically strong, well trained, persistently in high morale and equipped with the befitting wherewithal. Strength is derived from nutritious food intake and rigorous training. Personnel require the essentials which range from personal items, such as uniforms, gear and service arms to transportation. The deficiency and/or downgrades of any of the vital consumable products will certainly have an impact on the overall capacity to deliver on the objective.

\section{Conclusion}

As postulated in the "Social Contract Theory," every government derives the authority to govern based on the consent of the governed in return for security. Ideally, the primary obligation of every government is to ensure security of the populace through the national security framework. No other obligation supersedes this responsibility. Although national security agenda the world over encapsulate the range of security imperatives, there is an irrefutable dissonance in the discourse. The discourse is deficient because it limits greater public participation which essentially means the public's security priority may not always be accommodated. Also, it omits the consumer security lens to national security. The predominant variable in every national security is not the deterrent deployed to neutralize the security threats, but the enduring will and the capacity of the people and their perpetual desire to remain secure. The people serve a dual purpose: they are both the benefactors and the beneficiaries of national security. It is, therefore, imperative to duly incorporate the people's actual desires and needs into the national security composite.

\section{References}

Collins, A. (2013). Contemporary security studies. United Kingdom: Oxford University Press.

Government of Nepal Ministry of Defense. (2016). National security policy 2016. Retrieved from http://mod.gov.np//public/files/231574029National\%20Security\%20Policy,\%202016. pdf on January 16, 2020,

Kane, S. (2016, June 9). Here's the longest people have survived without air, food, water, sunshine, or sleep. Business Insider. Calfornia, Santa Monica: Rand National Defense Research Institute

Kugler, R. K. (1995). Towards a dangerous world U.S. national security strategy for the coming turbulence. Rand National Defense Research Institute. Singapore: Business Insider

National Security Concept of Mongolia. Retrieved from http://www.nsc.gov.mn/sites/default/ files/images/National $\% 20$ Security $\% 20$ Concept $\% 20$ of $\% 20$ Mongolia\%20EN.pdf on January 16, 2020

Phillips, M. (21 January 2009). President Obama's inaugural address. Retrieved from https://obamawhitehouse.archives.gov/ blog/2009/01/21/president-barack-obamasinaugural-address on 16 January 2020

Resolution by the Austrian parliament security \& defense doctrine. (2001). Retrieved from https://www.files.ethz.ch/isn/155910/ Austria-2001.pdf on 16 January 2020

Reuters. (2011, August 4). Cargill recalls 36 million pounds of turkey over Salmonella. Retrieved from https://www.reuters. com/article/us-salmonella-turkey-recallidUSTRE77301020110804 on January 16, 2020 , 
Staal, T. (2017, January). The national security strategy formulation process. Retrieved from https://issat.dcaf.ch/Learn/ResourceLibrary2/Videos/The-National-SecurityStrategy-Formulation-Process on 15 January 2020

The White House.(February 2015). National security strategy 2015. Retrieved from https:// obamawhitehouse.archives.gov/sites/default/ files/docs/2015 national_security_strategy_ 2 . pdf on January 17, 2020

The White House. (December 2017). National security strategy of the United States of America. Retrieved from https://www. whitehouse.gov/wp-content/uploads/2017/12/ NSS-Final-12-18-2017-0905.pdf on 16 January 2020
UNDP. (1994). Human development report 1994. New York: Oxford University Press.

United Kingdom Cabinet Office. (July 2019). National Sscurity strategy \& strategic defense \& security Review 2015. Retrieved from https://assets.publishing.service.gov. uk/government/uploads/system/uploads/ attachment_data/file/819613/NSS_and SDSR_2015_Third_Annual_Report_FINAL_2_.pdf on 16 January 2020

US Government Accountability Office. (December 2018). Long range emerging threats facing the United States as identified by federal agencies. Retrieved from https:// www.gao.gov/assets/700/695981.pdf on 17 January 2020 